\title{
KAIDAH HAFALAN AL-QURAN PADA MADRASAH TAHFIZ ANNUR MARKAZ YALA DAN MADRASAH DARUSSALAM RANGEK NARATTIWAT DI THAILAD SELATAN Ahmadzakee Mahama ${ }^{1}$ Phaosan Jehwae ${ }^{2}$
}

Abstract: This paper purpose to examine the rules of recitation of the al-Qur'an in Southern Thailand at Madrasah Annur Markaz Yala and Madrasah Darussalam. The author tries to see which rules are more practical to be practiced in the process of memorizing the al-Qur'an between the two rules. This study looks at current developments either at the stage of the academic Madrasah or in the religious section of each student in each method of guiding to memorize the al-Qur'an with the same time period of purpose as to memorize what is memorized. In this study is to see the good rules to use in order to give birth to the memorizers of the al- Qur'an are really good in terms of memorization. It will also be discussed about the law of memorizing the alQur'an, the advantages memorization of the al-Qur'an and the important of memorizing the al-Qur'an which in this study the authors will analyze and determine the student in one madrasah as many as 60 people with a share of 10 juz, 20 juz and 30 juz .

Keywords: Rule of memorize

Abstrak: Makalah ini bertujuan untuk mengkaji tentang kaidah hafalan alQuran di Selatan Thailand pada Madrasah Annur Markaz Yala dan Madrasah Darussalam. Penulis mencoba melihat kaidah manakah yang lebih praktikal untuk diamalkan dalam proses penghafalan al-Quran di antara dua kaidah tersebut. Kajian ini melihat kepada perkembangan masa sekarang baik pada tahap Madrasah akademik atau dibagian agama setiap pelajar dalam metode masing-masing membimbing pelajar menghafal al-Quran dengan waktu masa yang sama tujuan hanya supaya dapat menghafal apa yang dihafal. Dalam kajian ini adalah untuk melihat kaidah yang baik untuk digunakan agar melahirkan para penghafal al-Qur'an yang benar-benar baik dalam segi hafalannya. Selain itu juga akan dibahas mengenai hukum menghafal al-Quran, kelebihan menghafal al-Quran dan pentingnya menghafal al-Quran yang dalam kajian ini penulis akan menganalisa dan menentukan pelajar satu madrasah sebanyak 60 orang dengan dibagikan peringkat 10 juz, 20 juz, dan 30 juz.

Katakunci: kaidah hafalan

\footnotetext{
${ }^{1}$ Mahasiswa pada Jabatan Pengajian Islam, Fakulti Pendidikan, Universiti Fatoni, Thailand. Email: ahmadzakee@yahoo.com

2 Asst. Prof pada Jabatan Pendidikan Bahasa Melayu, Fakulti Pendidikan, Universiti Fatoni, Thailand. Email: fazdany@hotmail.com
} 


\section{Pendahuluan}

Al-Quran merupakan satu kitab wahyu yang diturunkan kepada Nabi Muhammad SAW Sebagai satu kebesaran Allah atau mukjizat tanda kenabian dan rasul Muhammad SAW. Kitab al-Quran adalah satu kitab yang mengandung cukup cara hidup manusia baik di dunnia dan di akhirat begitu juga yang hanya bukan sekadar dibaca, dikaji, dihafal, diamalkan malahan ia juga dihafal oleh para umat Islam baik menghafal separuh setengah atau keseluruhan ayat-ayat tersebut.

Sejarah pembelajaran al-Quran secara hafalan dimulai sejak turunnya ayat pertama dari al-Quran kepada Nabi Muhammad Sebagaimana dimaklumi dari berbagai nas bahawa beliau adalah seorang nabi yang ummi, yakni tidak tahu menulis dan membaca.Dalam keadaan yang ummi itulah Baginda Nabi Muhammad menerima al-Quran dari Malaikat Jibrail dan seterusnya menyampaikannya kepada para sahabat menerusi hafalan. Masyarakat Arab pada awal kenabian Muhammad s.a.w merupakan masyarakat yang buta huruf (ummi). Pendekatan pengajaran al-Quran dilakukan pada masa tersebut secara hafalan yang telah diaplikasikan oleh Malaikat Jibrail dalam mengajar al-Quran kepada Rasulullah (Al-Shabuni, 1996). Firman Allah S.W.T dalam surah alA'la ayat: 6 .

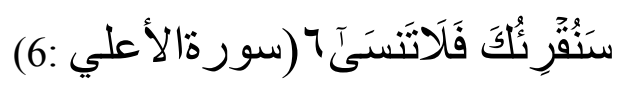

Artinya: Kami sentiasa menjadi engkau wahai Muhammad dapat membaca al-Quran yang diturunkan kepadamu dengan perantaraan Jibrail sehingga engkau menghafalnya dan tidak lupa (Abdullah Basmeih, 1999).

Allah akan terpelihara al-Quran dari permulaan diwahyukan kepada Nabi Muhammad sehingga hari kiamat dengan jaminan itu Allah menegaskan dalam al-Quran waktu yang tepat untuk menghafal, dan ini tergantung kepada pribadi masing-masing. Akan tetapi dalam suatu hadist yang diriwayatkan oleh Abu Hurairah ra, disebutkan bahwasanya Rasulullah bersabda:

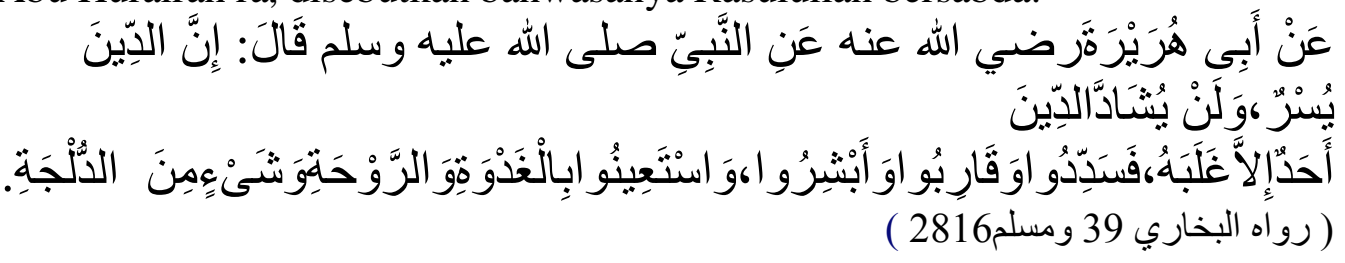


Artinya: Sesungguhnya agama ini mudah, dan tidak ada yang mempersulit diri dalam agama ini kecuali dia Akan capai sendiri, makanya amalkan agama ini dengan benar, pelan-pelan, dan berilah kabar gembira, serta gunakan waktu pagi, siang dan malam (untuk mengerjakannya) (HR Bukhari dan Muslim).

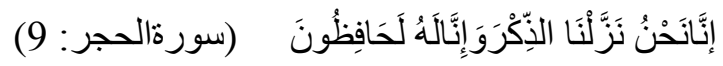

Artinya: Sesungguhnya Kamilah yang menurunkan al-Quran dan sesungguhnya kami benar-benar memeliharanya. (Al- hijr: 9).

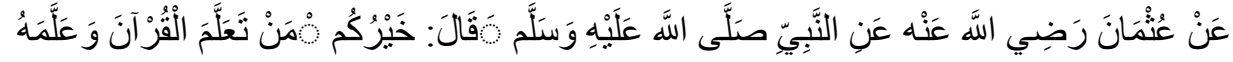

$$
\begin{aligned}
& \text { (صحيح البخاري : } 5027 \text { ) }
\end{aligned}
$$

Artinya; Sebaik-baik kalian adalah orang yang belajar al-Quran dan

mengajarkannya.(HR. Bukhori: 5027).

(HR. Bukhori: 5027)

Allah SWT memelihara al-Quran salah satu caranya adalah melalui penghafalan ayat-ayat al-Quran dengan cara yang bukan begitu payah hanya dengan mukjizat dan kelebihannya dengan itu berbagai kelebihan yang dibagi kepada penghafal al-Quran pasti memerlukan adanya satu-satu bentuk dan kaidah yang tertentu. Buat pada masa sekarang dapat dilihat banyak Madrasah dan tempat-tempat Tahfiz al-Quran dibangunkan. Dikalangan individu, pihak swasta dan sebagainya dengan berlomba-lomba bagi melahirkan hafiz al-Quran. Tetapi semuanya ada yang berhasil dan ada yang tidak berhasil ada dapat melahirkan huffaz dan ada sekadar hanya dapat sekadar mengenal membetulkan bacaan saja dalam hal pihak keluarga pelajar sendiri ingin dan mengharap bahawa anak-anak merika dapat Berhasil dengan membelajar hafalan al-Quran dan berhasil harapannya bulih menjadi huffaz. Dalam tesis ini pengkaji sendiri mencoba merungkai permasaalahan ini dengan melihat dari segi cara penggunaan dalam dua buah Madrasah tahfiz yang terpilih, bentuk atau kaidah manakah yang terlebih pakal bagi melahirkan para huffaz yang bulih mengingati hafalan yang terlebih tinggi dan baik dan melihat perbedaan kemampuan antara dua sekolah tersebut pihak penulis yakin bahwa dapat bulih menyelesaikan permasaalah apa yang dihadapi oleh para hufaz dalam mengingati hafalan dengan cepat serta melahirkan para hufaz yang berwibawaan dalam segi mengingati hafalan al-Quran. (Imam Nawawi, Al Majmu', (Beirut, Dar Al Fikri, 1996) Cet. Pertama, Juz: I, hal: 66). Pertama kali seseorang yang ingin menghafal Al Qur'am hendaknya mengikhlaskan niatnya hanya karena Allah subhanahuwataala saja. Dengan niat ikhlas, maka Allah Akan membantu anda dan menjauhkan anda dari rasa malas dan bosan. Suatu pekerjaan yang diniatkan ikhlas, biasanya Akan terus dan tidak berhenti. 
Berbeda kalau niatnya hanya untuk mengejar materi ujian atau hanya ingin ikut perlombaan, atau karena yang lain. Diriwayatkan bahwa Imam Ibnu Abi Hatim, seorang ahli hadits yang hafalannya sangat terkenal dengan kuatn hafalannya. Pada suatu ketika, Ia menghafal sebuah buku dan diulanginya berkali-kali, mungkin sampai tujuh puluh kali. Kebetulan dalam rumah itu ada nenek tua. Karena seringnya dia mengulang-ulang hafalannya, sampai nenek tersebut bosan mendengarnya, kemudian nenek tersebut memanggil Ibnu Abi Hatim dan bertanya kepadanya: Wahai anak, Apa kah yang sedang engkau kerjakan? "Saya sedang menghafal sebuah buku ", jawabnya. Berkata nenek tersebut: "Nggak usah seperti itu, saya saja sudah hafal buku tersebut hanya dengan mendengar hafalanmu." "Kalau begitu, saya ingin mendengar hafalanmu "kata Ibnu Abi Hatim, lalu nenek tersebut mulai mengeluarkan hafalannya. Setelah kejadian itu berlalu setahun lamanya, Ibnu Abi Hatim datang kembali kepada nenek tersebut dan meminta agar nenek tersebut menngulangi hafalan yang sudah dihafalnya setahun yang lalu, ternyata nenek tersebut sudah tidak hafal sama sekali tentang buku tersebut, dan sebaliknya Ibnu Abi Hatim, tidak ada satupun hafalannya yang lupa.Cerita ini menunjukkan bahwa mengulang-ulang hafalan sangatlah penting. Barangkali kalau sekedar menghafal banyak orang yang bisa melakukannya dengan cepat, sebagaimana nenek tadi. Bahkan kita sering mendengar seseorang bisa menghafal al-Qur'an dalam hitungan minggu atau hitungan bulan, dan hal itu tidak terlalu sulit, Akan tetapi yang sulit adalah menjaga hafalan dan mengulanginya secara berterusan. Pada dasarnya, setiap seorang hafiz itu memiliki suatu metode atau cara masing-masing di dalam menghafal al-Quran mengikut kesesuaian akalnya. Oleh yang demikian, setiap orang hafiz perlu memilih cara yang lebih berkesan, singkat masanya dan tahan lebih lama hafalannya. Berangkat dari masalah inilah, penyelidikan ini dilakukan terhadap kaidah hafalan al-Quran sistem Turki yang penyelidiki dan melihat amat efektif bagi mereka yang benar-benar mengabdikan hidupnya untuk al-Quran, karena sistem ini dilihat mempunyai keistimewaan tersendiri terutamanya dari segi jadwal hafalan, teknik hafalan serta tempoh masa yang singkat untuk menyelesaikan hafalan. Kesemua teori tersebut dianggap berhasil apabila ia dapat menggabungkan antara semangat pelajar dan komitmen guru (Abu Mazaayaa) (1996: 3).

Sejarah menghafal al-Quran di Fatoni Selatan Thailand secara resminya dimulai dengan pendirian Madrasah Tahfiz al-Quran pada tahun 1988. Pendirian ini dimulai dengan hasrat yang dicetuskan oleh para Tahfiz yang tamat belajar di negeri Pakistan dan India dengan sedikit perubahan yang sesuai dengan kondisi, yang ingin mengadakan sekolah tahfiz dikawasan tempatan. Dengan diberi nama Madrasah Tahfiz al-Quran Markaz Yala dan mula beroperasi di Mushalla, Markaz Yala. Sebagai permulaan, Maahad tahfiz ini didirikan sebagai salah satu unit di bawah jagaan markaz Jamaah Tabligh, dalam kawasan wilayah Yala Selatan Thailand dengan jumlah pelajar pada masa itu sebanyak 8 orang sebagai perantis yang dipilih. Kemudiannya madrasah tahfiz tersebut 
dibangunkan bangunan sebagai sekolah yang terpisah dengan kawasan masjid Pada tahun 1996. Setelah madrasahTahfiz di Markaz Yala, diikuti pula madrasah tahfiz yang dibuka di setiap kawasan Selatan Thailand dibawah pengurusan Markaz Yala. Pendirian MadrasahTahfiz di Selatan Thailand dimulai pada 2004 dengan menggunakan program Tahfiz al-Quran yang diakui setahap Objektif umum pendirian madrasah tahfiz al-Quran adalah untuk melahirkan huffaz, qurra' dan du'at yang mahir dan berketrampilan selaras dengan keperluan ummat. Manakala tujuan khusus kepada pendirian madrasah tahfiz ini adalah untuk melahirkan huffaz yang mahir dalam pembacaan dan pengajian ilmu al-Quran bagi memelihara kesucian dan kesahihan al-Quran dan seterusnya membentuk generasi al-Quran yang bertakwa, berilmu dan bermanfaat kepada masyarakat dan ummat. Kelas Alim atau kelas kitab adalah untuk pelajar yang telah tamat pengajian di kelas hafiz (khatam menghafal 30 juz al-Quran). Tempoh pembelajaran bagi kelas Alim mengambil waktu selama 8 tahun yang umumnya setiap tahun itu melambangkan setiap tingkat atau peringkat pengajian. Dan madrasah Darussalam ada satu madrasah swasta yang didirikan oleh tuan guru haji Daud bin haji yusuf bata pada tahun 1951 setelah balik pengajian di tanah suci Makkah al-Mukaramah. Pada tahun 1966 berganti cara pengajian dari cara berbentuk pondok kepada bentuk sekolah rakyat. Dan pada tahun 1969 sekolah dapat izin dari pihak pemerintah supaya dibolehkan membuka bagian agama dengan academik dan seterusnya dapat beralih kepada terlebih angkat dalam mata pembelajaran dan bertambah perlajar hingga akhirnya dan pada tahun 2007 pihak pengurus sekolah mengadakan program yang terbaru di bahagian Quran dan science program dan dapat sambutan yang baik dengan mengambil waktu belajar dan hafalan al- Quran selama 6 tahun Jadwal yang dijalankan di Madrasah Darussalam dengan peraturan berikut:

\begin{tabular}{|c|c|c|c|c|c|}
\hline \multicolumn{2}{|c|}{ Kelas pengajian } & Jumlah juz & Penggal 1 & Penggal 2 & Jumlah juz /setahun \\
\hline $\mathbf{1}$ & Mutawasit 1 & 4 & 2 & 2 & 4 \\
\hline $\mathbf{2}$ & Mutawasit 2 & 6 & 3 & 3 & 10 \\
\hline $\mathbf{3}$ & Mutawasit 3 & 6 & 3 & 3 & 16 \\
\hline $\mathbf{4}$ & Sanawi 1 & 7 & 4 & 3 & 23 \\
\hline $\mathbf{5}$ & Sanawi 2 & 7 & 4 & 3 & 30 \\
\hline $\mathbf{6}$ & Sanawi 3 & \multicolumn{5}{|c|}{ Murajaah 30 juz } \\
\hline
\end{tabular}

\begin{tabular}{|c|c|c|c|}
\hline \multicolumn{2}{|c|}{ Kaidah dan Cara hafaz al-Quran } & Masa hafalan \\
\hline $\begin{array}{c}\text { Hafaz } 10 \\
\text { mukasurat }\end{array}$ & 1 hari & $\begin{array}{l}\text { 1.lepas makharib } \\
\text { baris }\end{array}$ \\
\hline 1 mukasurat & 30 baris & 3 hari & 2.lepas fajar 3 \\
baris \\
3.dalam kelas 4 \\
baris
\end{tabular}

\section{Ketetapan murajaah pada tahun ahkir (tahun 6)}




\begin{tabular}{|c|cc|}
\hline Kali 1 & Hafaz 1 juz 4 hari 30 juz $=120$ hari \\
\hline Kali 2 & Hafaz 1 juz 2 hari 30 juz $=60$ hari \\
\hline Kali 3 & Hafaz 1 juz 1 hari 30 juz $=30$ hari \\
\hline \multicolumn{3}{|c|}{ Jumlah masa untuk murajaah semua 210 hari $(7$ bulan $)$} \\
\hline
\end{tabular}

Kajian ini melihat kepada perkembangan masa sekarang baik pada tahap Madrasah academic atau dibahagian agama setiap pelajar dalam metode masing-masing membimbing pelajar menghafal al-Quran dengan waktu masa yang sama tujuan hanya supaya dapat menghafal apa yang dihafal. Dalam kajian ini adalah untuk melihat kaidah manakah yang lebih terbaik untuk digunakan untuk melahirkan para hafiz yang benar-benar mantap dalam bidang hafalannya. Dalam kajian ini pengkaji akan analisa menentukan pelajar satu Madrasah 60 orang dengan dibagikan peringkat 10 juz, 20 juz, dan 30 juz. Tujuan kajian ini adalah seperti berikut: Untuk mengkaji sejarah perkembangan latar belakang ilmu hafalan di Selatan Thailand. Untuk memperkenalkan kaidah-kaidah hafalan al-Quran di Selatan Thailand. Untuk mengkaji cara-cara hafalan al-Quran menurut kaidah hafalan di Madrasah Annur Markaz yala dan kaidah di Madrasah Darussalam. Untuk mengkaji perbedaan yang berkemampuan hafalan al-Quran diantara kaidah Madra Sah Annur Markaz Yala dan Madrasah Darussalam supaya mengenal kaidah manakah Yang Lebih berkesan untuk digunakan. Berpandu apa yang dituliskan pengkaji akan dapat menjawab beberapa pertanyaan yang melalui kajian ini yaitu, bagaimana sejarah perkembangan ilmu hafalan al-Quran di Selatan Thailand. Apakah bentuk bentuk kaidah hafalan al-Quran yang terdapat di Selatan Thailand. Bagaimana bentuk cara cara hafalan al-Quran menurut kaidah hafalan di Madrasah Annur markaz Yala dan kaidah di Madrasah Darussalam. Adakah terdapat perbedaan yang berkemampuan hafalan al-Quran diantara kaidah Madrasah Annur di Markaz Yala dan di Madrasah Darussalam supaya mengenal kaidah manakah yang lebih berkesan untuk digunakan.

\section{Hukum Menghafal al-Quran}

Al-Quran yang terdiri dari 114 surah dan 30 juz merupakan satu-satunyakitab suci yang boleh dihafal secara keseluruhan. Ini adalah suatu kelebihan kepada umat baginda Rasulullah SAW dan penghafalan al-Quran adalah rahmat dari Allah S.W.T. Jika dibandingkan dengan buku-buku lain yang sama tebal dan besarnya, menghafal satu buku, setengah buku atau pun seperempat buku adalah sukar dan hampir-hampir mustahil. Allah S.W.T. menyifatkan penghafaz al-Quran sebagai hamba-hamba pilihannya. Hal ini dinyatakan menerusi firmanNya:

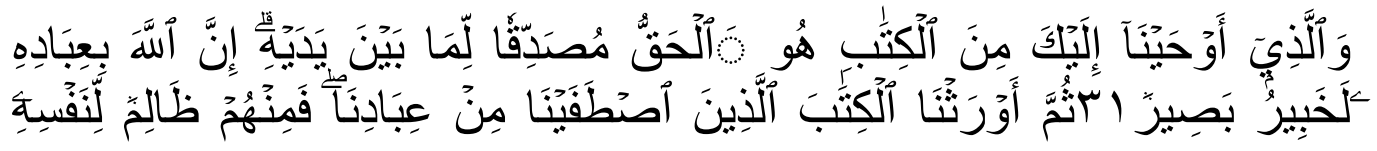




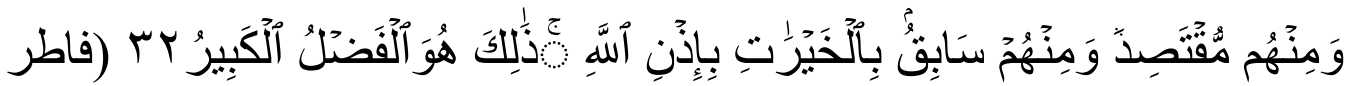

(32-31:

Artinya: Dan apa yang telah Kami wahyukan kepada mu iaitu al-Kitab (alQuran) itulah yang benar, dengan membenarkan kitab-kitab yang sebelumnya. Sesungguhnya Allah benar-benar Maha Mengetahui lagi Maha Melihat (keadaan) hamba-hambanya. Kemudian Kitab itu Kami wariskan kepada orang-orang yang kami pilih di antara hamba-hamba Kami, lalu di antara merekaada yang menganiaya diri mereka sendiri dan di antara mereka ada yang pertengahan dan di antara mereka ada (pula) yang lebih dahulu berbuat kebaikan dengan izin Allah. Yang demikian itu adalah kurnia yang amat besar (Fatir: 31-32).

Ayat-ayat yang lain juga menyatakan bahawa al-Quran diturunkan dengan menerusi hafalan secara beransur-ansur lebih kurang 23 tahun. Ayat-ayat yang dimaksudkan adalah:

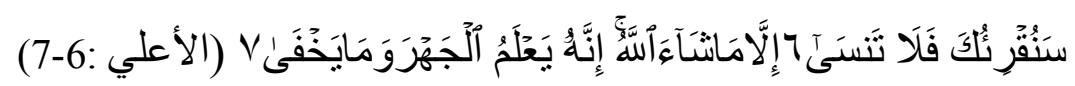

Artinya: Kami akan membacakan (al-Quran) kepada mu (Muhammad) maka kamu tak akan lupa, kecuali kalau Allah menghendaki. Sesungguhnya Dia mengetahui yang terang dan yang tersembunyi.(alA'la: 6-7).

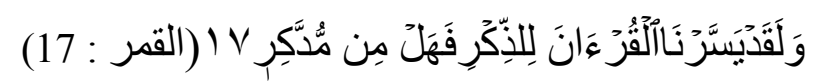

Artinya: Dan sesungguhnya telah kami mudahkan al-Quran untuk pelajaran, maka adakah orang yang mengambil pelajaran (al-Qamar:17).

Dari ayat-ayat di atas, tidak ada satu pun isyarat yang menyatakan bahawa menghafal al-Quran itu hukumnya wajib. Karena itu menghafal al-Quran bukanlah sesuatu yang wajib ke atas setiap muslim. Walau bagaimanapun memandangkan betapa pentingnya menghafal al-Quran bagi menjaga keaslian dan kesuciannya maka ulama telah bersepakat bahawa menghafal al-Quran itu hukumnya fardu kifayah. Imam Badr al-Din Muhammadbin 'Abdillah alZarkasyi di dalam bukunya al-Burhan fil Ulum al-Quran (Juz 1: 271) menyatakan: "Mempelajari al-Quran hukumnya adalah fardu kifayah, demikian juga memeliharanya (iaitu menghafalnya) maka ia juga wajib (kifayah) bagi setiap umat." Perkara yang sama juga dinyatakan oleh Ab. Aziz Ab. Rauf (1994: 90) di dalam bukunya Kiat Sukses Menjadi Hafidz al-Quran Da'yah seperti berikut: "Sesungguhnya menghafal al-Quran di luar kepala (maksudnya denganlancar) itu adalah fardu kifayah." Hukum fardu kifayah ini bermakna sekiranya sudah ada di antara kaum muslimin di suatu tempat yang menghafal 
al-Quran, maka lepaslah tanggungjawab kesemua masyarakat tersebut dari kewajipan itu. Sebaliknya jika tiada seorang pun yang menghafalnya maka seluruh kaum muslimin pada tempat tersebut akan menerima dosa.

\section{Kelebihan Menghafal Al-Quran}

Menjadi seorang hafiz sepatutnya menjadi cita-cita setiap orang Islam karena mereka akan mendapat berbagai keutamaan dan kelebihan baik di dunia lebih lebih lagi di alam akhirat. Menjadi hafiz merupakan nikmat rabbani yang datangnya dari Allah S.W.T. karena kelebihan menghafal al-Quran samanilainya dengan nikmat kenabian, cuma bedanya tidak diberi wahyu. Seorang hafizal-Quran akan diberi nikmat di alam kubur lagi meskipun kesusahan, kepayahan dan huru hara di alam akhirat amat dahsyat. Jasadnya akanterpelihara seperti keadaan asalnya tanpa dirosakkan oleh sesuatu pun sedangkan tubuh orang lain tidak terkecuali darinya. Hafizal-Quran merupakan orang yang mendapat penghargaan khusus dari NabiMuhammad SAW. Penghargaan seumpama ini pernah diberikan oleh baginda ketika pengkebumian para syuhada' yang hafaz al-Quran seperti yang diriwayatkan dalam sebuah hadith:

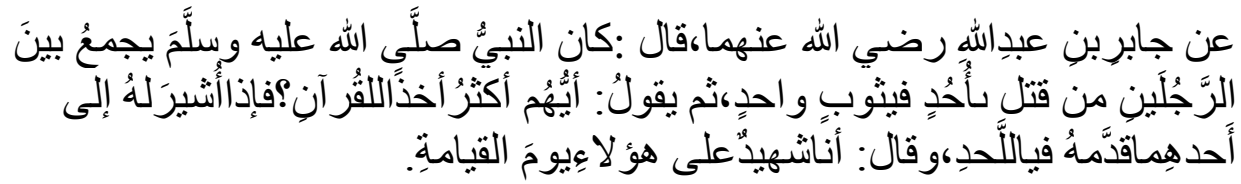

Artinya : Dari Jabir bin Abdullah R.A., bahawa suatu ketika Rasulullah SAW mengumpul dua orang lelaki yang syahid dalam peperangan Uhud dalam satu liang lahad, lalu baginda bertanya, "Siapakah di antara kedua-dua ini yang paling banyak menghafal al-Quran?”. Apabila ditunjukkan kepada baginda salah seorang dari mereka maka Nabi akan mendahulukan pengkebumiannya lalu bersabda, "Aku menjadi saksi terhadap mereka.

(Hadis Riwayat Bukhari, Abu Dawud dan Nasa'i)

Manakala dalam hadith lain baginda Rasulullah S.A.W telah bersabda:

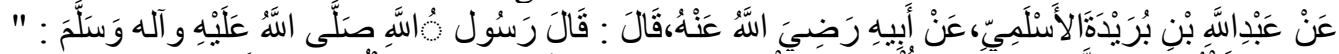

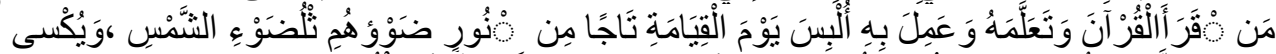

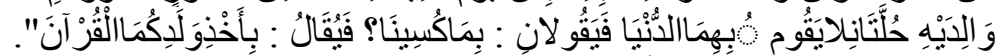

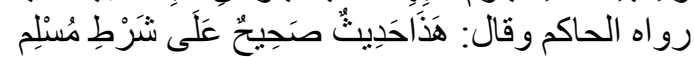

Artinya: Sesiapa yang membaca al-Quran dan belajar serta beramal dengannya, dia akan dipakaikan pada hari kiamat dengan mahkota dari cahaya yang mana cahayanya lebih terang dari cahaya matahari, dan kedua ibu bapaknya akan dipakaikan dengan perhiasan yang tidak pernah mereka pakai di dunia. Maka mereka berdua bertanya, "Dengan sebab apakah kami dipakaikan dengan perhiasan ini?. Mereka akan dikatakan: Dengan sebab bacaan al-Quran oleh anakmu (Hadith riwayat al-Hakim). 
Menurut al-Kattabi sebagaimana yang dinukilkan oleh al-Mundhiri bahawa jumlah ayat al-Quran adalah sama dengan jumlah tingkat syurga di akhirat. Para hafiz al-Quran akan diseru pada masa itu supaya terus menaiki tingkat syurga mengikut kadar jumlah ayat al-Quran yang telah dibacanya semasa di dunia (Zakiy al-Din, 1993: 213). Kesimpulannya, para hufaz al-Quran bukan saja dipandang mulia di duniamalah di akhirat kelak mereka akan turut mendapat berbagai pengiktirafan dari Allah S.W.T.

\section{Kepentingan Menghafal al-Quran}

Menghafal al-Quran adalah suatu ibadah dan mempunyai matlamat dan tujuan yang penting. Antaranya ialah: Memelihara emutawatiran al-Quran bermakna "al-Quran yang sampai kepada kita dengan diriwayatkan oleh jumlah orang yang banyak dan mereka mempunyai sifat dan ciri-ciri amanah sehingga tidak diragukan lagi atas kedustaan atau kepalsuan al-Quran itu sendiri." Melalui para huffaz yang ribuan jumlahnya dan berterusan disepanjang sejarah kehidupan manusia tidak mudah bahkan mustahil untuk mengubah dan memalsukan al-Quran. Seandainya terjadi perubahan atau penyelewengan, maka merekalah dahulu yang menyedarinya. Hafizul-Quran menjadi benteng untuk mempertahankan kemutawatiran al-Quran dari musuh-musuh Islam yang sentiasa mencari peluang untuk menghancurkan Islam. Firman Allah S.W.T.:

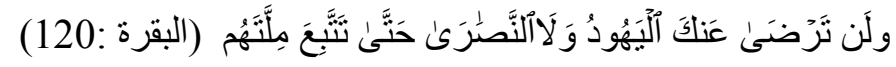

Artinya: "Orang-orang Yahudi dan Nasrani tidak akan reda dengan kamusehingga kamu mengikuti agama mereka........"

(Al-Baqarah: 120 )

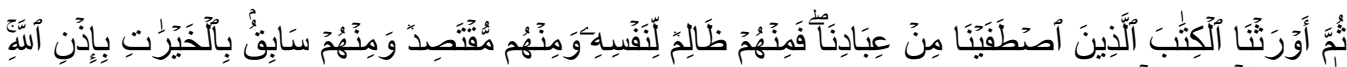

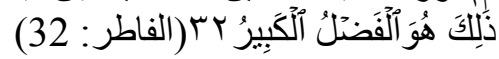

Artinya: Kemudian kitab itu kami wariskan kepada orang-orang yang kami pilih diantara hamba-hamba kami lalu diantara mereka ada yang menganinya diri merika sendiri dan diantara merika ada yang pertengahan dan diantara merika ada (pula) yang lebih dahulu berbuat kebaikan dengan izin Allah yang demikian itu adalah kurnia yang amat besar.

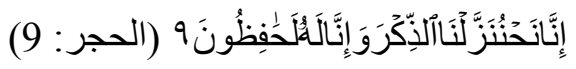

Artinya: Sesungguhnya kamilah yang menurunkan al-Quran dan sesungguhnya kami benar- benar memeliharanya. 
Rasulullah SAW juga memberi penghormatan dengan menyifatkan hafiz alQuran sebagai Ahlullah iaitu keluarga Allah dan meletakkan kedudukan mereka hampir kepada para nabi, cuma yang membezakan mereka tidak menerima wahyu.

\section{Memelihara Kesinambungan Budaya Ulama-Ulama Salaf}

Sejarah membuktikan bahawa ulama-ulama silam (Salaf al-Sholeh) telah membacaal-Quran dengan baik serta menghafalnya. Mereka kemudiannya telahmempelajarinya secara terperinci, mengembangkan ilmu dan menghasilkan kitab kitab tafsir yang muktabar dan dapat dijadikan rujukan sepanjang zaman. Dizaman Rasulullah SAW telah lahir para qari dan hafiz alQuran yang terkenalseperti Ubai bin Kaab R.A., Abu Musa al-Asyaari R.A. Abu Sa'id al-Kudri R.A.dan lain-lain lagi sementara di zaman perkembangan ilmu pengetahuan telahlahirnya para Imam Qiraat seperti Imam Nafi' bin Ruwaim, Ibn Katsir, A'shim binAbi al-Najud, Muhammad bin Muhammad alJazari serta banyak lagi. Jelaslahdisini bahawa melalui hafalan al-Quran, dapat memelihara kesinambungan budaya Salaf al-Sholeh dari zaman awal Islam sehingga ke zaman ini.

\section{Al-Quran Sebagai khazanah Ilmu}

Al-Quran adalah "Manhaj al-Hayah" atau pedoman hidup bagi seluruh manusiatanpa batasan. Bertepatan dengan sifat Allah S.W.T. yang Maha Pencipta dan Maha Mengetahui, al-Quran yang merupakan perkataannya sarat dengan ilmu pengetahuan. Dalam perjalanan memahami luasnya ilmu dalam alQur'an, dialektika antara manusia dengan realitasnya ditengarai turut masuk mempengaruhi proses penafsiran itu. Karena memang, pada dasarnya al-Qur'an diturunkan bagi manusia, untuk kemaslahatan manusia dan untuk memanusiakan manusia (bukan menjadikannya makhluk otomatis seperti robot, mesin, hewan ataupun malaikat) (Razzaq, 2016: 91). Di dalamnya terkandung berbagai khazanah ilmu baik ilmu ukhrawi ataupun duniawi. Seseorang yang menghafal dan menguasai al-Quranbermakna ia telah memiliki berbagai ilmu baik dari segi pendidikan, ekonomi politik dan sebagainya. Sebagai umat Islam, kita tiada alasan untuk meragukan Keagungannya. Firman Allah S.W.T. di dalam al-Quran:

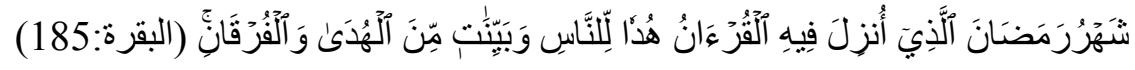

Artinya: Bulan Ramadan adalah bulan yang diturunkan padanya alQuransebagai petunjuk bagi manusia dan beberapa keterangan yangmembawa kepada petunjuk bagi manusia dan beberapaketerangan yang membawa kepada petunjuk dan membezakan diantara yang benar dan yang salah.........(al-Baqarah: 185). 


\section{Memelihara Kesucian Moral dan Sosial Dalam Masyarakat}

Aktivitas penghafalan al-Quran dapat menangani gejala keruntuhan moral dan sosial. Di zaman yang penuh ujian ini, masyarakat memerlukan suatu jalan sebagai alternatif untuk kemaslahatan umat keseluruhannya. Membentuk generasi al-Quran adalah yang terbaik. Firman Allah S.W.T:

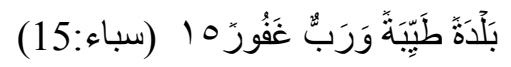

Artinya: (Negeri mu) adalah negeri yang terbaik dan (Tuhanmu)adalah Tuhan yang maha pengampun (Saba':15)

Seorang yang asyik dengan pengajian dan penghafalan al-Quran akan terselamat dari kelalaian dan kemaksiatan karena penumpuan hati manusia tidak mampu mengumpul dua perkara yang bertentangan dalam satu mana. Firman AllahS.W.T.

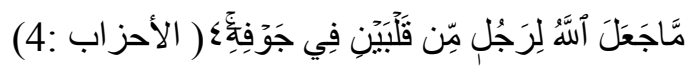

Maksudnya: Allah tidak sekali-kali menjadikan dua hati bagi seseorang dalam dirinya......

(al-Ahzab: 4)

Al-Quran akan menjadi pemelihara kepada seorang hafizdari sebarang dosaatau maksiat karena sebarang larangan dari Allah S.W.T. akan sentiasa teringat didalam ingatannya. Dengan bertambahnya hufaz di kalangan umat Islam makamasalah sosial dalam masyarakat akan dapat diatasi.

\section{Penutup}

Islam mulai masuk ke kawasan Fatoni Selatan Thailand pada abad ke-10 atau ke 11 lewat jalur perdagangan. Fatoni merupakan salah satu kawasan yang makmur di negara Thailand, baik secara politik maupun administratif. Kerajaan Fatoni berakhir setelah dikalahkan kerajaan Siam dari Bangkok. Pendidikan Islam di Fatoni dimulai sejak Islam datang dan menetap di Fatoni yaitu pada abad ke-15, pendidikan dasar dimulai di kalangan masyarakat Islam dengan mempelajari Al-Quran.Proses Islamisasi di Pattani tidak bisa dilepaskan dari peranan pendidikan. Pada tahap awal, pendidikan informal sangat berperan, yaitu kontak informal antara mubaligh dengan rakyat setempat selanjutnya ditindak lanjuti dengan munculnya pendidikan non formal dan terakhir pendidikan formal. Adapun lembaga pendidikan di Fatoni selatan Thailand diantaranya adalah masjid atau surau, pondok tradisional, pondok modern, madrasah, sekolah dan perguruan tinggi. Kemudian untuk metode pengajaran di 
Fatoni selatan Thailand dapat dikelompokkan menjadi tiga macam metode yaitu metode sorogan, metode bandungan dan metode weton. Membuat masa sekarang Madrasah Tahfiz al-Quran makin berkembang dengan baik dan mendapat sambutan yang sangat menggalakkan lebih-lebih lagi pada zaman yang serba moden ini.

\section{Daftar Pustaka}

\section{Buku dan Tesis}

Al-Quran dan Terjemahnya kepada Bahasa Indonesia. (1412 H), Raja Fahad ibn Abd al-Aziz al-Saud, Madinah al-Munawarah, Saudi Arabia.

Abdul Hafiz (2006). Modul Pengajaran Ulum al-Quran. Skudai: Pusat Pengajian Islam Dan Pembangunan Sosial.

Abdul Hafiz Bin Abdullah (2008). Modul Bengkel Teknik Menghafal Al-Quran Siri 4, "Kaidah Hafalan Sistem Turki”. Johor Bahru: Universiti Teknologi Malaysia.

Abdul Hafiz Bin Haji Abdullah et.al (2003). "Keberkesanan Kaidah Hafalan Di Pusat Tahfiz". Skudai: Universiti Teknologi Malaysia.

Abdul Muhsin Al Qasim. (2007).”Cara Praktis Menghafal Al Quran”. (Imam dan Khatib Masjid Nabawi) Maktab Dakwah Dan Bimbingan Jaliyat Rabwah.

Razzaq, Abdur dan Deden Mula Saputra (2016). Studi Analisis Komparatif Antara Ta'wil dan Hermeneutika dalam Penafsiran al-Qur'an. Journal Wardah: Vol. 17 No. 2 (89-114). Wardah: Vol/Juli-Desember 2016.

Rosli Husin (2000). Al-Quran Sumber Pendidikan. Kuala Lumpur: Al-Hidayah Publisher. Kod Kursus : HBIS 1203 (2012) . PENGAJIAN ASUHAN TILAWAH AL-QURAN, Fakulti pendidikan dan bahasa.Teuku Iskandar (2005). Kamus Dewan Edisi Keempat. Kuala Lumpur: Dewan Bahasa dan Pustaka.

Sedek bin Ariffin (2011). Kaidah menghafal al-Quran di Institusi tahfiz alQuran di Malaysia Kajian perbandingan diantara kaidah Darul Quran Jakim dengan kaidah Al-Huffaz. Jabatan al-Quran dan al-Hadith Akademi Pengajian Islam Universiti Malaya Kuala Lumpur.

Sheikh 'Abdullah Basmeih (2000). Tafsir Pimpinan al-Rahman kepada Pengertian al- Quran (30 Juz). Kuala Lumpur: DarulFikir.

Norlita Binti Mohd Alias (2003). “Kaidah Hafalan al-Quran' Satu Kajian Di Maahad Tahfiz Al-Quran Wal Qiraat Addin, Tualang Sekah, Daerah Malim Nawar, Perak Darul Ridzuan.

Nurayah Binti Aminin, (2012), pengajian asuhan tilawah al-Quran. Faculty of education and Languages.

Phaosan Jehwae, (2010) Kaidah hafalan al-Quran dan kajian. Terjemahan dari bahasa Thai dari beberapa kajian Madrasah di Thailand. 
Wardah, Vol.18, No.2, 2017

Ahmadzakee Mahama

Phaosan Jehwae

\section{Sumber Internet}

http://www.islam.gov.my/en/buku-kaidah-hafalan-al-quran

http://www.iqt.terengganu.gov.my/

http://www.darulquran.gov.my/

Al-Amin. (2010) http://www.al-amin.edu.my. Diakses Januari 21. 